\title{
IMPLEMENTATION OF SCIENTIFIC APPROACH WITH CONCRETE MATERIALS TO IMPROVE MATHEMATICS LEARNING OUTCOMES ABOUT PLANE FIGURES TO FOURTH GRADE STUDENTS OF SDN MENGKOWO IN ACADEMIC YEAR OF 2019/2020
}

\author{
Sumayyah ${ }^{1}$, Wahyudi ${ }^{2}$, Ratna Hidayah ${ }^{3}$ \\ Sebelas Maret University \\ sumayyah_99@student.uns.ac.id
}

\section{Article History}

accepted 01/06/2020

approved 01/07/2020

published 01/08/2020

\begin{abstract}
Implementation of Scientific Approach with Concrete Materials to Improve Mathematics Learning Outcomes about Plane Figures to Fourth Grade Students of SDN Mengkowo In Academic Year of 2019/2020. The purposes of the study were: (1) to describe the steps of scientific approach with concrete materials in improving mathematics learning outcomes about plane figures, (2) to improve mathematics learning outcomes about plane figures with scientific approaches and concrete materials, (3) to describe obstacles and solutions for implementing scientific approaches with concrete media in improving mathematics learning outcomes about plane figures. The study was classroom action research conducted in three cycles and six meetings. The subjects were teacher and 31 students of fourth grade at SDN Mengkowo. Types of data were qualitative data and quantitative data. Data collection techniques used observation, interviews, and tests. Data validity used triangulation of techniques and triangulation of sources. Data analysis included data reduction, data presentation, and drawing conclusions. The results indicated that: (1) the steps of scientific approach with concrete materials involved: (a) observing concrete materials, (b) asking questions based on materials, (c) gathering information from the media, (d) experimenting, and (e) communicating; (2) the implementation of scientific approach with concrete materials improved mathematics learning outcomes about plane figures to fourth grade students of SDN Mengkowo in academic year of 2019/2020; (3) the obstacle was found in the fifth step which was communicating. The students were not confident in delivering the result of group discussion. The solution was the teacher asked one of the groups to deliver the result of discussion and gave rewards.
\end{abstract}

Keywords: scientific approach, concrete materials, learning outcomes, mathematics

\begin{abstract}
Abstrak: Implementasi Pendekatan Saintifik dengan Media Konkret untuk Meningkatkan Hasil Belajar Matematika tentang Bangun Datar pada Siswa Kelas IV SDN Mengkowo Tahun Ajaran 2019/2020. Tujuan penelitian ini yaitu : (1) Mendeskripsikan langkah-langkah implementasi pendekatan saintifik dengan media konkret, (2) meningkatkan hasil belajar Matematika tentang bangun datar, dan (3) mendeskripsikan kendala dan solusi pada implementasi pendekatan saintifik. Penelitian tindakan kelas kolaboratif ini dilaksanakan dalam tiga siklus enam pertemuan. Subjek penelitian ini adalah guru dan siswa SDN Mengkowo. Data yang digunakan berupa data kualitatif dan kuantitatif. Teknik pengumpulan data menggunakan observasi, wawancara, dan tes. Validitas data menggunakan triangulasi teknik dan sumber. Analisis data dilaksanakan melalui reduksi data, penyajian data, dan penarikan kesimpulan. Hasil penelitian ini yaitu: (1) implementasi pendekatan saintifik dengan media konkret untuk meningkatkan hasil belajar Matematika tentang bangun ruang dilaksanakan dengan langkahlangkah : a. mengamati media konkret, b. menanya berdasarkan media, c. mengumpulkan informasi dari media, d. menalar, dan e. mengkomunikasikan; (2) pendekatan saintifik dengan media konkret dapat meningkatkan hasil belajar matematika tentang bangun datar pada siswa kelas IV SDN Mengkowo tahun ajaran 2019/2020; (3) kendala yang muncul yaitu pada langkah ke lima mengkomunikasikan, siswa kurang percaya diri dalam menyampaikan hasil diskusi kelompok. Solusi yang dapat diterapkan adalah guru menunjuk pada salah satu kelompok untuk menyampaikan hasil diskusi dan memberikan penghargaan.

Kata Kunci: Pendekatan Saintifik, Media Konkret, Hasil Belajar, Matematika
\end{abstract}




\section{PENDAHULUAN}

Pada abad 21 ini dibutuhkan sistem pendidikan yang dapat menciptakan sumber daya manusia yang berkualitas, yaitu pribadi yang berkemauan, mandiri dan berkemampuan untuk mewujudkan cita-cita bangsanya. Melalui pendidikan harus dapat membantu peserta didik memiliki kemampuan berpikir kritis. US-based Partnership for 21st Century Skills (P21), mengidentifikasi kompetensi yang diperlukan di abad ke- 21 yaitu "The 4Cs"- communication, collaboration, critical thinking, dan creativity (Zubaidah, 2016: 3). Dari keempat kompetensi tersebut diterapkan oleh Pemerintah Indonesia pada Kurikulum 2013 yang dikenal dengan keterampilan 4C. Oleh karena itu seorang guru harus mengusai kompetensi yang menunjang profesionalitasnya supaya dapat mempersiapkan peserta didik dalam menghadapi kebutuhan pendidikan abad 21. Kesuksesan proses pembelajaran terletak pada kesiapan guru dalam mengenal karakteristik siswa, kemampuan guru dalam memadukan materi, media, sumber belajar, lingkungan, dan kurikulum akan menentukan keberhasilan proses pembelajaran.

Berkaitan dengan hal tersebut, salah satu mata pelajaran yang ada di SD yaitu matematika. Matematika merupakan salah satu mata pelajaran yang sangat perlu mendapat perhatian lebih, karena pentingnya matematika dalam kehidupan sehari-hari (Sholihah \& Mahmudi, 2015: 183). Matematika sangat penting diajarkan dan dilaksanakan di SD, maka pada saat pembelajaran guru hendaknya dapat menciptakan situasi pembelajaran yang memungkinkan untuk meningkatkan keaktifan siswa dalam mencari penyelesaian terhadap suatu permasalahan serta mengembangkan kemampuan berpikir siswa dalam kegiatan pembelajaran sehingga tujuan pembelajaran yang telah ditentukan oleh guru dapat tercapai dan akan terlihat dari hasil belajar siswa.

Berdasarkan hasil observasi pembelajaran Matematika di kelas V dan wawancara dengan guru kelas V SDN Mengkowo pada hari Kamis, 7 November 2019, didapatkan informasi bahwa (1) dalam pembelajaran guru sudah menggunakan pendekatan saintifik meskipun belum semua langkah berjalan optimal, (2) siswa cenderung pasif, (3) beberapa siswa kurang menguasai materi, (4) hasil belajar siswa rendah hal ini dibuktikan dengan nilai PTS (Penilaian Tengah Semester) hanya ada $45,16 \%$ atau 14 siswa yang mendapat nilai di atas KKM.

Dari uraian di atas, alternatif pemecahan masalah yang dianggap sesuai untuk mengatasi permasalahan tersebut adalah dengan menggunakan pendekatan saintifik. Sejalan dengan pendapat Koro-koro (2016: 14) yang menyatakan pendekatan saintifik tepat digunakan dalam pembelajaran matematika untuk meningkatkan hasil belajar. Hosnan (2016: 34) mengungkapkan pendekatan saintifik adalah konsep pembelajaran yang dirancang sedemikian rupa agar siswa aktif. Alasan mengapa menggunakan pendekatan saintifik sebagai alternatif pemecahan masalah tersebut karena ,pendekatan saintifik merupakan cara yang menarik dan sistematis untuk mengeksplorasi pengetahuan yang melibatkan kepada anak-anak dalam kegiatan mengamati, menanya, memprediksi, mencoba, meringkas, dan menyampaikan hasil (Gerde, Schachter, dan Wasik, 2013: 315) Dengan menggunakan pendekatan saintifik ini siswa akan dituntut aktif dalam proses pembelajaran sehingga setelah pembelajaran siswa akan segera mendapatkan hasil dari materi yang dipelajari.

Selain menggunakan pendekatan saintifik, alternatif lain untuk memecahkan masalah yang ada di kelas IV SDN Mengkowo yaitu peneliti menggunakan media pembelajaran, Salah satu media yang cocok digunakan adalah media konkret karena disebutkan dalam penelitian Nugrohoningdyah (2013: 2) bahwa media konkret tepat digunakan dalam pembelajaran matematika. Media konkret adalah benda yang dapat dilihat, didengar atau dialami oleh peserta didik sehingga memberikan pengalaman secara langsung (Asyhar, 2011:54). Pembelajaran menggunakan media benda konkret 
memberikan pengalaman riil/nyata, sehingga pengalaman belajar yang lebih konkret akan lebih tepat bagi anak usia sekolah dasar (Sumarjilah, 2015: 70). Untuk itu peneliti memilih media konkret untuk diterapkan karena sesuai dengan karakteristik siswa kelas IV SD.

Berdasarkan latar belakang di atas maka peneliti tertarik untuk mengadakan penelitian tindakan kelas yang bertujuan untuk: (1) Mendeskripsikan implementasi pendekatan saintifik dengan media konkret untuk meningkatkan hasil belajar matematika tentang bangun datar pada siswa kelas IV SDN Mengkowo tahun ajaran 2019/2020, (2) Meningkatkan hasil belajar matematika tentang bangun datar dengan pendekatan saintifik dan media konkret pada siswa kelas IV SDN Mengkowo tahun ajaran 2019/2020, (3) Mendeskripsikan kendala dan solusi implementasi pendekatan saintifik dengan media konkret untuk meningkatkan hasil belajar matematika tentang bangun datar pada siswa kelas IV SDN Mengkowo tahun ajaran 2019/2020.

\section{METODE PENELITIAN}

Penelitian ini merupakan penelitian tindakan kelas yang dilaksanakan secara kolaboratif antara peneliti dengan guru kelas. Adapun prosedur penelitian ini menggunakan model penelitian tindakan kelas yang terdiri dari empat tahapan, yaitu (1) perencanaan, (2) pelaksanaan, (3) observasi, dan (4) refleksi. Penelitian ini dilakukan dalam tiga siklus. Masing-masing siklus terdiri dari dua pertemuan dengan alokasi waktu 70 menit setiap pertemuan. Subjek penelitian ini adalah seluruh siswa kelas IV SDN Mengkowo tahun ajaran 2019/2020 dengan jumlah 31 siswa yang terdiri dari 11 siswa laki-laki dan 20 siswa perempuan.

Data yang digunakan dalam penelitin ini berupa data kualitatif berupa implementasi pendekatan saintifik dengan media konkret dan kuantitatif berupa data mengenai hasil belajar Matematika tentang bangun datar. Sumber data dalam penelitian ini yaitu siswa kelas IV, guru kelas IV, dan dokumen Adapun teknik pengumpulan data yang digunakan adalah observasi, wawancara, dan tes. Uji validitas data menggunakan triangulasi teknik dan sumber. Teknik analisis data yang digunakan dalam penelitian ini yaitu reduksi data, penyajian data, dan penarikan kesimpulan sesuai model analisis data menurut Miles dan Huberman (Sugiyono, 2011: 247-253).

Aspek yang diukur dalam indikator kinerja penelitian ini adalah pelaksanaan langkah-langkah pendekatan saintifik dan ketuntasan hasil belajar setelah mengimplementasikan pendekatan saintifik dan media konkret dengan persentase yang ditargetkan sebesar $85 \%$.

\section{HASIL DAN PEMBAHASAN}

Proses pembelajaran dilaksanakan dengan langkah-langkah: (1) mengamati media konkret, (2) menanya berdasarkan media, (3) mengumpulkan informasi dari media, (4) menalar (berdiskusi dengan teman sekelompok) dan (5) mengkomunikasikan. Langkah-langkah yang digunakan oleh peneliti mengacu pada langkah-langkah yang dikemukakan oleh Suyanto (2018: 23) dan Atmarizon dan Zaim (2016: 4-5), kemudian peneliti melakukan modifikasi langkah tersebut dengan menggunakan media konkret dan disimpulkan menjadi langkah yang telah disebutkan di atas. Hasil observasi pendekatan saintifik dengan media konkret mengalami peningkatan pada setiap siklusnya hingga mencapai indikator kinerja penelitian yang ditargetkan sebesar $85 \%$. 
Tabel 1. Persentase Hasil Observasi pendekatan saintifik dengan media konkret terhadap guru dan siswa

\begin{tabular}{lcccc}
\hline \multirow{2}{*}{ Sumber Data } & \multicolumn{3}{c}{ Siklus } \\
\cline { 3 - 5 } & & I & II & III \\
\hline Guru & Persentase (\%) & 86,86 & 90,71 & 95,04 \\
\hline Siswa & Persentase (\%) & 85,44 & 89,92 & 93,72 \\
\hline
\end{tabular}

Berdasarkan tabel 1, diketahui bahwa proses pembelajaran pada siklus I, II, dan III selalu meningkat. Peningkatan hasil pengamatan terhadap guru dari siklus I ke siklus II sebesar 3,85\%, dari siklus II ke siklus III mengalami peningkatan sebesar $4,33 \%$. Peningkatan hasil pengamatan terhadap siswa dari siklus I ke siklus II sebesar $4,48 \%$, dari siklus II ke siklus III mengalami peningkatan sebesar 3,80\%. Pada siklus III, baik guru dan siswa, hasil pengamatan sudah mencapai target yaitu $85 \%$.

Tabel 2. Analisis Hasil Belajar Siswa Siklus I, II, dan III

\begin{tabular}{ccccc}
\hline No & Siklus & \multicolumn{3}{c}{ Tuntas (\%) } \\
\cline { 3 - 5 } & & Pertemuan I & Pertemuan II & Rata-rata \\
\hline 1 & I & 83,87 & 87,10 & 85,48 \\
2 & II & 87,10 & 90,32 & 88,71 \\
3 & III & 93,55 & 96,77 & 95,16 \\
\hline
\end{tabular}

Berdasarkan tabel 2, diketahui bahwa rata-rata ketuntasan hasil belajar siswa setelah guru mengimplementasikan pembelajaran dengan pendekatan saintifik dengan media konkret pada siklus I, II, dan III selalu meningkat. Peningkatan persentase siswa yang tuntas dari siklus I ke siklus II sebesar 3,23\%, dari siklus II ke siklus III sebesar $6,45 \%$. Rata-rata ketuntasan pada siklus III sebesar 95,16\% sudah mencapai target indikator kinerja penelitian yaitu $85 \%$.

Pendekatan saintifik akan menumbuhkan minat belajar siswa yang akan membuat siswa lebih aktif dan menuntut siswa untuk berfikir kritis dan kreatif. Data di atas membuktikan pendapat Zhong (2014: 1507-1508) di dalam penelitiannya mengemukakan bahwa pendekatan saintifik dapat merangsang dan memancing minat siswa dalam belajar dan didukung juga dengan pendapat Abidin (Aprianita, 2015: 691692) menguraikan beberapa keunggulan pendekatan saintifik dalam pembelajaran yaitu: (1) memandu siswa dalam memecahkan masalah, (2) menuntut siswa untuk berpikir kritis, kreatif, logis dan sistematis, (3) mengembangkan karakter siswa, dan (4) melatih siswa dalam beragumentasi dan berkomunikasi. Menurut penjelasan tersebut pendekan saintifik dapat meningkatkan hasil belajar siswa, seperti yang disebutkan dalam penelitian Wartini, Lasmawan, \& Marhaeni (2014: 3) menyatakan pendekatan saintifik dapat mengoptimalkan hasil belajar siswa.

Alasan mengapa hasil belajar meningkat setelah diimplementasi pendekatan saintifik dengan media konkret ialah (1) mengamati diterapkan pada pembelajaran agar dapat meningkatkan rasa keingintahuan siswa, seperti yang dikemukan oleh Machin (2014: 31) mengamati bermanfaat bagi pemenuhan rasa ingin tahu peserta didik, sehingga proses pembelajaran memiliki kebermaknaan yang tinggi dan diinovasikan menggunakan media benda nyata karena siswa akan lebih tertarik pada benda yang nyata, sehingga lebih memudahkan siswa untuk memahami materi yang disampaikan, ketika siswa paham dengan materi maka akan berpengaruh pada hasil belajar siswa. Hal tersebut diperkuat dari penelitian relevan yang di dalamnya menyatakan rasa ingin tahu berpengaruh positif terhadap prestasi belajar siswa mata pelajaran IPA kelas V SD (Aji, 2017: 87) (2) menanya akan memunculkan rasa ingintahunya sehingga siswa menjadi lebih kritis, sperti yang dikemukakan oleh indriyanti, Mulyasari, dan sudarya (2017: 16) dengan bertanya akan mengembangkan 
pola berpikir dan cara belajar aktif dari siswa. Jadi, ketika siswa aktif bertanya maka siswa akan lebih paham terhadap materi yang kurang mereka pahami dan hal tersebut berpengaruh pada hasil belajar siswa. Hal tersebut diperkuat dengan penelitian relevan oleh Husna (2017: 16) menyatakan tingkat berpikir kritis siswa memiliki hubungan yang signifikan terhadap hasil belajar siswa. (3) mengumpulkan informasi dengan cara mencoba menggunakan media yang tersedia karena dengan mencoba akan menumbuhkan rasionalitas siswa dalam berpikir kritis dan bertindak, dengan itu siswa dapat menemukan sendiri berbagai jawaban serta siswa dapat terlatih dalam cara berfikir yang ilmiah. seperti yang dikemukakan oleh Ovia dan maulidar (2014: 338) dengan mencoba siswa akan menemukan sendiri berbagai jawaban atau persoalanpersoalan yang dihadapi serta siswa juga dapat terlatih dalam cara berfikir yang ilmiah. Sejalan dengan penelitian Sabarudin (2019: 30) menyatakan salah satu karakteristik dalam pembelajaran memecahkan masalah adalah belajar menemukan konsep secara mandiri. Tujuan dari kegiatan ini guru dapat mengetahui kemampuan siswa yang nantinya akan berpengaruh pada hasil belajar siswa. Hal tersebut diperkuat oleh penelitian sebelumnya yang menyatakan terdapat hubungan positif antara kemandirian belajar dengan hasil belajar siswa (Rahmawati, 2016: 91). (4) menalar akan melatih siswa dalam berkolaborasi dengan temannya dan akan lebih kritis dalam memecahkan masalah, seperti yang dikemukakan oleh Sari dan Dewi (2017: 2) siswa yang berfikir semakin kritis dan kreatif akan menjamin ilmu pengetahuan yang diperoleh akan bertahan lebih lama sehingga akan berdampak pada hasil belajar siswa yang semakin meningkat. Hal tersebut diperkuat dalam penelitian sebelumnya Enry, Haji \& Widada (2017: 20) yang menyatakan terdapat hubungan timbal balik antara kemampuan pemecahan masalah matematika dalam kegiatan diskusi dengan kemampuan berpikir tingkat tinggi siswa (5) mengkomunikasikan tujuannya agar siswa berani mengemukakan pendapat mereka dan melatih siswa untuk lebih percaya diri, hal tersebut akan berpengaruh pada proses pembelajaran dan hasil belajar siswa. Hal tersebut dikuatkan oleh penelitian relevan dari Ameliah, Munawaroh \& Muchyidin (2016: 19) menyatakan terdapat pengaruh antara rasa percaya diri siswa dengan hasil belajar matematika siswa.

Dari keseluruhan yang telah dibahas, pendekatan saintifik efektif untuk meningkatkan hasil belajar siswa. Dalam penelitian ini hasil belajar akan difokuskan pada ranah kognitif atau peng etahuan. Oleh karena itu, hasil belajar pada aspek kognitif yang diukur dalam penelitian ini dapat meningkat. Hasil penelitian diatas memperkuat penelitian sebelumnya yang dilakukan Irwanto, Wasitohadi dan Rahayu (2019: 283-284) permasalahan yang didapat yaitu siswa mengalami kesulitan dalam pembelajaran matematika, hasil belajar yang masih rendah, guru dalam mengajar belum menggunakan media di dalam kelas, kemudian peneliti menggunakan pendekatan saintifik sekaligus media konkret untuk meningkatkan hasil belajar matematika siswa kelas IV SD, hasil yang didapat ialah pendekatan saintifik dengan media konkret dapat meningkatkan hasil belajar matematika siswa kelas IV SD. Dengan demikian implementasi pendekatan saintifik dengan media konkret dapat meningkatkan hasil belajar Matematika tentang bangun datar yang dilihat dari persentase siswa yang memenuhi ketercapaian target dari siklus I-III. Dibuktikan dengan penelitian Wartini, Lasmawan, \& Marhaeni (2014: 3) yang menyatakan pendekatan saintifik dapat mengoptimalkan hasil belajar siswa.

Kendala pendekatan saintifik dengan media konkret untuk meningkatkan hasil belajar Matematika tentang bangun datar pada siswa kelas IV SDN Mengkowo tahun ajaran 2019/2020 yaitu: (1) guru belum mengarahkan siswa menulis kesimpulan, (2) siswa kurang aktif bertanya, (3) guru kurang membangkitkan motivasi bertanya, (4) guru kesulitan membimbing siswa, (5) siswa mengobrol sendiri, (6) siswa mengganggu kelompok lain saat diskusi, (7) penyimpulan didominasi guru, (8) kelas terlalu ramai, (9) kesadaran siswa untuk mencacat masih kurang, (10) siswa kurang percaya diri dalam 
menyampaikan hasil diskusi. Adapun solusi untuk mengatasi kendala di atas yaitu: (1) guru lebih mempersiapkan pembelajaran pada pertemuan selanjutnya, (2) mengarahkan siswa untuk bertanya, (3) guru memberikan motivasi kepada siswa, (4) guru menjelaskan dengan bahasa yang mudah dipahami, (5) guru mengingatkan dan memfokuskan siswa, (6) guru memberi teguran, (7) guru mengajak siswa untuk menyimpulkan bersama, (8) guru menyelingi pemberian penghargaan berupa pujian, (9 siswa diingatkan untuk mencacat, (10) guru menunjuk pada salah satu kelompok untuk menyampaikan hasil diskusi dan memberikan penghargaan

\section{SIMPULAN}

Berdasarkan uraian di atas, dapat disimpulkan:

1. Impelementasi pendekatan saintifik dengan media konkret untuk meningkatkan hasil belajar Matematika tentang bangun datar pada siswa kelas IV SDN Mengkowo tahun ajaran 2019/2020 dilaksanakan dengan langkah-langkah: (1) mengamati media konkret, (2) Menanya berdasarkan media, (3) mengumpulkan informasi dari media, (4) menalar atau berdiskusi kelompok, dan (5) mengkomunikasikan.

2. Implementasi pendekatan saintifik dengan media konkret dapat meningkatkan hasil belajar Matematika tentang bangun datar pada siswa kelas IV SDN Mengkowo tahun ajaran 2019/2020, ditunjukkan dengan peningkatan persentase siswa pada setiap siklus yang memenuhi ketercapaian target indikator penelitian sebesar $85 \%$.

3. Kendala impelementasi pendekatan saintifik dengan media konkret untuk meningkatkan hasil belajar Matematika tentang bangun datar pada siswa kelas IV SDN Mengkowo tahun ajaran 2019/2020 yaitu: (1) guru belum mengarahkan siswa menulis kesimpulan, (2) siswa kurang aktif bertanya, (3) guru kurang membangkitkan motivasi bertanya, (4) guru kesulitan membimbing siswa, (5) siswa mengobrol sendiri, (6) siswa mengganggu kelompok lain saat diskusi, (7) penyimpulan didominasi guru, (8) kelas terlalu ramai, (9) kesadaran siswa untuk mencacat masih kurang, (10) siswa kurang percaya diri dalam menyampaikan hasil diskusi. Adapun solusi untuk mengatasi kendala di atas yaitu: (1) guru lebih mempersiapkan pembelajaran pada pertemuan selanjutnya, (2) mengarahkan siswa untuk bertanya, (3) guru memberikan motivasi kepada siswa, (4) guru menjelaskan dengan bahasa yang mudah dipahami, (5) guru mengingatkan dan memfokuskan siswa, (6) guru memberi teguran, (7) guru mengajak siswa untuk menyimpulkan bersama, (8) guru menyelingi pemberian penghargaan berupa pujian, (9 siswa diingatkan untuk mencacat, (10) guru menunjuk pada salah satu kelompok untuk menyampaikan hasil diskusi dan memberikan penghargaan.

Berkaitan dengan hasil penelitian yang telah dicapai maka dapat disampaikan saran-saran sebagai berikut: (1) siswa sebaiknya lebih berani menyampaikan gagasan atau pendapat ketika berdiskusi maupun ketika kegiatan presentasi, (2) guru hendaknya membimbing siswa agar lebih percaya diri dan berani bertanya, menjawab dan berpendapat pada saat kegiatan diskusi berlangsung, (3) sebaiknya sekolah menyediakan fasilitas, sarana, dan prasarana serta mendukung guru untuk berinovasi dalam menggunakan pendekatan atau model dan media pembelajaran untuk meningkatkan kualitas pembelajaran, (4) Pembaca/Peneliti lain hendaknya membuat kegiatan pembelajaran yang lebih inovatif dan kreatif. Salah satunya yaitu dengan memodifikasi implementasi pendekatan saintifik dengan media konkret. 


\section{DAFTAR PUSTAKA}

Aprianita, R. (2015). Menerapkan Pendekatan Saintifik yang Berorientasi pada Kemampuan Metakognisi dan Keterampilan Sosial. Seminar Nasional Matematika dan Pendidikan Matematika UNY, hlm. 689-696. Yogyakarta: Program Studi Pendidikan Matematika Universitas Negeri Yogyakarta.

Aji, W.H., (2017). Pengaruh Disiplin Belajar dan Rasa Ingin Tahu terhadap Prestasi Belajar IPA Siswa Kelas V SD Gugus 5 Kecamatan Pengasih Kabupaten Kulon Progo Yogyakarta. Skripsi. Universitas Negeri Yogyakarta, Yogyakarta.

Ameliah, H.I., Munawaroh, M., \& Muchyidin, A. (2016). The Influence Of Curiosity And Self-Confidence Of Students Toward Outcome Studied Mathematics Grade Vii Mts Negeri 1 Cirebon. EduMa, 5 (1), 9-21.

Asyhar, R. (2011). Kreatif Pengembangan Media Pembelajaran. Jakarta: Gaung Persada Press

Atmarizon, D. \& Zaim, M. (2016). The Implementatio $n$ of Scientific Approach in Teaching English at the Tenth Grade of Senior High School 7 Padang. Jurnal Pendidikan Bahasa, Sastra, dan Seni, 17 (1), 2-17.

Enry, Haji, S., \& Widada, W. (2017). Pengaruh Pendekatan Saintifik pada Pembelajaran Matematika terhadap Kemampuan Pemecahan Masalah dan Kemampuan Berpikir Tingkat Tinggi Siswa Kelas X IPA SMA Negeri 1 Kepahiang. Jurnal Pendidikan Matematika Raflesia. 2(1), 1-22.

Gerde, H.K., Schachter, R.E., \& Wasik, B.A. (2013). Using The Scientific Methode to Guide Learning: An Integrated Approach to Early Childhood Curriculum. Early Chilhood Education Journal, 41 (5), 315-323.

Hosnan. (2016). Pendekatan Saintifik dan Kontekstual dalam Pembelajaran Abad 21. Bogor: Ghalia Indonesia

Husnah, M. (2017). Hubungan Tingka Berpikir Kritis terhadap Hasil Belajar Fisika Siswa dengan Menerapkan Model Pembelajaran Problem Based Learning. Journal of Physics and Science Learning (PASCAL). 1 (2), 10-17.

Indriyanti, Mulyasari, E., \& Sudarya, Y. (2017) Penerapan Pendekatan Saintifik untuk Meningkatkan Keterampilan Bertanya Siswa Kelas V SD. Jurnal Pendidikan Guru Sekolah Dasar. 2 (2), 13-25.

Irwanto, Wasitohadi, \& Rahayu, T.S. (2019) Penerapan Pendekatan Scientific dengan Menggunakan Media Konkret untuk Meningkatkan Hasil Belajar Matematika Siswa Kelas 4 SD. Jurnal Riset Teknologi dan Inovasi Pendidikan, 2 (1), 280288.

Machin, A. (2014). Implementasi Pendekatan Saintifik, Penanaman Karakter dan Konservasi pada Pembelajaran Ateri Pertumbuhan. Jurnal Pendidikan IPA Indonesia. 3(1), 28-35.

Nugrohoningdyah. (2013). Pemanfaatan Media Benda Konkret pada Pembelajaran Tematik untuk Meningkatkan Hasil Belajar Matematika di Sekolah Dasar. JPGSD, 1 (2), 1-11.

Oviana, W. \& Maulidar. (2014). Penggunaan Metode Eksperimen pada Pembelajaran Materi Sifat Bahan dan Kegunaanya terhadap Hasil dan Respon Belajar Siswa Kelas IV MIN Tungkob Aceh Besar. Jurnal IImiah DIDAKTIKA. 13 (2), 336-350.

Rahmawati, D. (2016). Hubungan antara Kemandirian Belajar dengan Hasil Belajar Siswa SD Negeri Purwoyoso 06 Semarang. Skripsi. Universitas Negeri Semarang. Semarang

Sabaruddin. (2019). Penggunaan Model Pemecah Masalah untuk Meningkatkan Kemampuan Berpikir Analisis Peserta Didik pada Materi Gravitasi Newton. Lantanida Journal. 7 (1), 1-13. 
Sari, P.D. \& Dewi, M.R. (2017). Pengaruh Keterampilan Berpikir Kritis dan Berpikir Kreatif Terhadap Hasil Belajar Mata Pelajaran Ekonomi kelas X IPS 1 di MAN Mojosari. Jurnal Pendidikan Ekonomi, 5 (1), 1-8.

Solihah, D.A. \& Mahmudi, A. (2015). Keefektifan Experiential Learning Pembelajaran Matematika Mts Materi Bangun Ruang Sisi Datar. Jurnal Riset Pendidikan Matematika, 2 (2), 175-185.

Sugiyono. (2016). Metode Penelitian Kuantitatif, Kualitatif dan R\&D. Bandung: Alfabeta Bandung

Sumarjilah, Y. (2015). Pengunaan Media Kongkrit untuk Meningkatkan Hasil Belajar Matematika Pokok Bahasan Penjumlahan dan Pengurangan Bilangan Pada Siswa Kelas I Sdn Rejoagung 01 Kabupaten Jember. PANCARAN PENDIDIKAN FKIP Universitas Negeri Jember, 4 (4), 69-78.

Suyanto, S. (2018). The Implementation of the Scientific Approach Through 5MS of the Revised Curriculum 2013 in Indonesia. Jurnal Ilmiah Pendidikan, (1), 22-29.

Wartini, I.A.K.M., Lasmawan, I.W.,\& Marhaeni. (2014). Pengaruh Implementasi Pendekatan Saintifik terhadap Sikap Sosial dan Hasil Belajar Matematika di Kelas VI SD Jembatan Budaya, Kuta. E-Journal Program Pascasarjana Universitas Pendidikan Ganesha Program Studi Pendidikan Dasar, 4.

Zhong, G.Q. (2014). Training of scientific Thinking methods in teaching of inorganic analytical chemistry. Journal Of Chemical Pharmaceutical Research, 6 (7), 1503-1508.

Zubaidah, S. (2016). Keterampilan Abad Ke-21: Keterampilan yang Diajarkan melalui Pembelajaran. Artikel pada Seminar Nasional Pendidikan dengan Tema "Isuisu strategi Pembelajaran MIPA Abad 21, hlm.1-17. Kalimantan Barat: Program Studi Pendidikan Biologi STKIP Persada Khatulistiwa Sintang. 